\title{
Current Diagnosis and Treatment Models of Periodic Fever, Aphthous Stomatitis, Pharyngitis and Cervical Lymphadenitis Syndrome
}

\section{Periyodik Ateș, Aftöz Stomatit, Farenjit ve Servikal Lenfadenit Sendromuna Güncel Tanı ve Tedavi Yaklașımları}

\author{
Ayşenur Paç Kısaarslan¹, Emel Kabakoğlu Ünsür², Betül Sözeri \\ 'University of Health Sciences, Ümraniye Training and Research Hospital, Clinic of Pediatric Rheumatology, Istanbul, Turkey \\ ${ }^{2}$ Erciyes University Faculty of Medicine, Department of Pediatrics, Division of Pediatric Nephrology, Kayseri, Turkey
}

\begin{abstract}
Periodic fever, aphthous stomatitis, pharyngitis, and cervical lymphadenitis (PFAPA) syndrome is the most frequent cause of periodic fever in childhood. The pathogenesis of PFAPA is still unknown. Differantial diagnosis must be made with cyclic neutropenia and other autoinflammatory diseases. Because PFAPA is self limiting and benign, there is no certain treatment model. Treatment options must be specific to the patient, with a strong family and doctor relationship.

Keywords: Periodic fever, aphthous stomatitis, pharyngitis, and cervical lymphadenitis syndrome, diagnosis, therapy
\end{abstract}

ÖZ

Periyodik ateş, aftöz stomatit, farenjit ve servikal lenfadenit(PFAPA) sendromu çocukluk çağında görülen, en sık tekrarlayan ateş nedenidir. PFAPA patogenezi halen tam olarak bilinmemektedir. Siklik nötropeni ve diğer monogenik otoenflamatuvar hastalıklarla ayırıcı tanısının yapılması gerekmektedir. Kendini sınılayan ve benign bir hastalık olduğu için henüz netlik kazanmış bir tedavi şekli yoktur. Tedavi seçeneklerinin ise güçlü bir ebeveyn-doktor ilişkisi yardımılla hastaya özel olarak seçilmesi gerekmektedir.

Anahtar Kelimeler: Periyodik ateş, aftöz stomatit, farenjit ve servikal lenfadenit sendromu, tanı, tedavi

\section{Periodic Fever, Aphthous Stomatitis, Pharyngitis, and Cervical Lymphadenitis Syndrome}

Periodic fever, aphthous stomatitis, pharyngitis, and cervical lymphadenitis (PFAPA) syndrome is the most frequent cause of recurrent fevers in childhood. It was first described by Marshall et al. (1) in 1987. PFAPA is diagnosed with recurrent episodes of fever continuing for 3-6 days and following 3 to 8-week intervals; with at least one of the following findings:
Aphthous stomatitis, cervical lymphadenitis, and pharyngitis. The disease often starts before the age of 5 and mostly ends in adolescence. The general condition, growth and development of patients are normal between the episodes $(1,2)$.

\section{Epidemiology}

Most of the patients are between the ages of 2 and 5 with mild male predominance and no racial or ethnic

\section{Address for Correspondence/Yazıșma Adresi}

Betül Sözeri MD, University of Health Sciences, Ümraniye Training and Research Hospital, Clinic of Pediatric Rheumatology, Istanbul, Turkey

Phone: +90 5327629003 E-mail: betulsozeri@yahoo.com

Received/Geliş tarihi: 01.09.2015 Accepted/Kabul tarihi: 26.10.2015

${ }^{\circ}$ Copyright 2017 by Ege University and Ege Children's Foundation

The Journal of Pediatric Research, published by Galenos Yayınevi. 
predominance (3). Rarely, familial cases have been reported $(4,5)$. In the majority of patients the attacks last until the age of 10 , but it has also been reported in adults (6).

\section{Pathogenesis}

Autoinflammatory syndromes are a group of diseases characterized by inflammatoryattacks that occurindependently of autoreactive $T$ lymphocytes or external triggering agents. The common termination of genes associated with these syndromes is interleukin (IL)-1 $\beta$ activation. Although the pathogenesis of PFAPA syndrome is not fully understood, it is evaluated in autoinflammatory syndromes. Studies have shown that IL-1 $\beta, I L-18$, tumor necrosis factor- $\alpha$, interferon (IFN)- $\gamma$ from proinflammatory cytokines increase in the early phase of fever and IL-6 increases rapidly in the late phase (7-12). In contrast, levels of T-cell-associated cytokines IL-7, IL-17 and anti-inflammatory cytokines IL-10 and IL-4 decrease during exacerbation (8). Dysregulation of $\mathrm{IL}-1$ production from monocytes has been shown in patients (9). In addition, increased expression of inflammation-associated genes (AIM2, CASP1) and IL-1 were detected during the episode (11). In the fever episodes, dysregulation in natural immunity together with an increase in Th1 response, and reduction in Th2 response lead to changes in cytokine levels $(8-10,12)$. Increased levels of monocytes, and decreased levels of eosinophiles and lymphocytes are observed during exacerbations $(9,10)$.

Genetic background is one of the most controversial features of this syndrome. Although it is generally accepted as a sporadic disease, familial clustering suggests the presence of a possible hereditary component (13). The link to genes associated with other autoinflammatory diseases has been investigated. Specifically observed was the MEFV mutation which plays a modifying role in PFAPA disease activation and it has been determined that with MEFV mutations the duration of attacks are irregular and shorter, the frequency of aphthous stomatitis and the need for glucocorticoid treatment is rare (14).

In a large cohort study, 68 individuals and 14 families were enrolled to elucidate the genetic orientation of PFAPA syndrome. It was suggested that PFAPA is not a monogenic disease, but polygenic and/or is influenced by non-genetic factors (15).

\section{Clinical Findings}

In a multicentre cohort analysis by Hofer et al. (16), 301 patients with PFAPA were evaluated and clinical manifestations were reported. The study results reported so far are presented in Table I $(2,8,17-21)$. Fever starts suddenly with shudders. Body temperature ranges from 38.9 to 41.1 ${ }^{\circ} \mathrm{C}$ for 3-6 days. The period between fever episodes is around 28.2 days (26-30.4 days). The average number of attacks is 11.5 per year $(2,14)$. Aphthous ulcer is frequently seen on the lips and in buccal mucosa, accompanied by fever attacks in $40-70 \%$ of cases, and heals without scarring $(2,16,17)$. Pharyngitis is detected in $90 \%$ of the patients. Exudative pharyngitis occurs in $41 \%$ of the cases (17). Cervical adenopathy is associated with $78 \%$ of attacks, and $86 \%$ is bilateral (17). Adenopathy is sensitive to touch. The clinical findings may also be accompanied by headache, muscle aches, diarrhea, arthralgia, cough and flu-like symptoms, and rash.

\section{Laboratory Findings}

There is no diagnostic laboratory test. Attacks may be diagnosed as tonsillitis or viral infection. Group A Streptococcus can be detected in $9.8 \%$ of cases in the throat culture (2). PFAPA attacks do not respond to penicillin therapy. C-reactive protein (CRP) is high at the beginning of the attack, sedimentation may

\begin{tabular}{|c|c|c|c|c|c|c|c|}
\hline & $\begin{array}{l}\text { Thomas et al. } \\
\text { (2) }\end{array}$ & $\begin{array}{l}\text { Padeh et al. } \\
\text { (17) }\end{array}$ & $\begin{array}{l}\text { Tasher et al. } \\
\text { (18) }\end{array}$ & $\begin{array}{l}\text { Gattorno et al. } \\
\text { (19) }\end{array}$ & $\begin{array}{l}\text { Feder and Salazar } \\
\text { (20) }\end{array}$ & $\begin{array}{l}\text { Wurster et al. } \\
\text { (21) }\end{array}$ & $\begin{array}{l}\text { Stojanov et al. } \\
\text { (8) }\end{array}$ \\
\hline Number of patients & 66 & 28 & 54 & 130 & 105 & 59 & 21 \\
\hline Pharyngitis (\%) & 65 & 100 & 96 & 83.8 & 85 & 75 & 86 \\
\hline Cervical adenitis (\%) & 77 & 100 & 61 & 83.8 & 62 & 88.3 & 100 \\
\hline Aphthous stomatitis (\%) & 67 & 68 & 39 & 58.5 & 38 & 71.7 & 62 \\
\hline Headache (\%) & 65 & 18 & 46 & 40.8 & 44 & 70 & - \\
\hline Abdominal pain $(\%)$ & 45 & 18 & 65 & 53.1 & 41 & 33.3 & 57 \\
\hline Diarrhea $(\%)$ & 30 & - & 13 & 29.2 & - & - & 10 \\
\hline Arthralgia (\%) & - & 11 & - & 43.8 & - & 26.7 & 29 \\
\hline Trembling (\%) & 80 & - & 61 & - & - & 83.3 & - \\
\hline Skin eruption (\%) & 15 & - & 4 & 22.3 & - & - & 10 \\
\hline
\end{tabular}


be normal but it may increase after a few days (20). Procalcitonin does not increase like other acute phase reactants (22). Serum immunoglobulin (lg) levels are normal, lgD is normal or slightly elevated $(20,23)$. All inflammatory parameters return to normal between the attacks (22).

\section{Differential Diagnosis}

Cyclic neutropenia, whose attacks occur at specific intervals, is the most important differential diagnosis (2). Cyclic neutropenic episodes occur every 18-24 days and the absolute neutrophil count falls below $500 / \mathrm{mm}^{3}$ during the attack. Promyelocytic arrest is detected in the bone marrow, and attacks do not respond to steroid therapy (24). Many monogenic autoinflammatory diseases may emerge with regular attacks and mimic or coincide with PFAPA syndrome. Especially in hyperimmunoglobulinemia D syndrome, familial Mediterranean fever and tumor necrosis factor receptorassociated periodic syndrome patients, PFAPA-like findings can be seen. Further research should be done if there are coughs, colds, severe abdominal pain, severe diarrhea, rash, arthritis and neuromuscular symptoms, increased acute phase response between episodes, and family history of periodic fever. In 2008, Gattorno et al. (19) formed a gaslini scoring system to help further investigation, which is recommended if the total score is higher than 1.32 in this scoring system, where abdominal pain, aphthous stomatitis, chest pain, presence of diarrhea, as well as the age at the onset of symptoms and family history are questioned.

\section{Treatment}

Since PFAPA syndrome is a self-limiting and benign disease, there is no clear treatment yet. The family and the physician should decide on the treatment together considering potential side effects, and social factors such as not being able to go to work and/or school in this febrile period (25). Clinical experience has shown that paracetamol and nonsteroid anti-inflammatory drugs used in the treatment of PFAPA syndrome can not control symptoms other than fever.

Glucocorticoids: The administration of $1-2 \mathrm{mg} / \mathrm{kg}$ prednisolone at the onset of fever will control fever and pharyngitis, but not aphthous stomatitis and adenitis. This rapid response has a diagnostic feature that also helps to distinguish PFAPA syndrome from other periodic fever syndromes $(6,20)$. However, glucocorticoids have been shown to shorten the time between attacks in $25 \%$ of patients (26). Symptoms may recur within 48-72 hours after the first dose (27). In this case, prednisolone $1 \mathrm{mg} / \mathrm{kg}$ on days 1 and $2 ; 0.5 \mathrm{mg} / \mathrm{kg}$ on day 2 and 3 can be repeated. There are studies recommending a single dose of betamethasone 10.3 $\mathrm{mg} / \mathrm{kg}$ ) at the onset of fever as an alternative to this treatment (23). In some recent uncontrolled studies, low-dose $(0.6 \mathrm{mg} /$ $\mathrm{kg} / \mathrm{g}$ ) prednisolone therapy has also been shown to improve the symptoms (24). The most frequently reported side effects of glucocorticoid therapy are-restlessness and sleep disturbance. These may be reduced if the prednisolone dose is given 4-6 hours before bedtime.

Tonsillectomy: Because PFAPA syndrome has a spontaneous remission, tonsillectomy, which has possible risks, is a controversial treatment. It is reported that in $1 / 3$ of the patients symptoms repeat $0.5-10$ years after tonsillectomy (25). In another study evaluating the efficacy of the treatment, steroid therapy $(90 \%)$, tonsillectomy (75\%), tonsillectomy and adenoidectomy (86\%) were found successful (2). According to the results obtained from the meta-analysis performed by Burton et al. (28), tonsillectomy ( \pm adenoidectomy) was an effective treatment in children with PFAPA, and post-operative symptoms occurred four times more slowly. There was also a significant decrease in the number of PFAPA attacks and the use of corticosteroids after tonsillectomy. However, due to the disadvantages inherent in the surgical procedure, the choice of patients to be offered this treatment should be done carefully.

Among the less frequently applied therapies are colchicine, anti IL-1 and vitamin D treatments. In a study group in which colchicine treatment was given at $0.5-1 \mathrm{mg} /$ day together with prednisolone, there was a decrease in the frequency of attacks (18). However, routine use of colchicine in the treatment of PFAPA is not recommended because of its short term effect, and the lack of studies on a sufficient number of patients (25). IL-1 $\beta$ has been seen to elevate during PFAPA attacks. Acting on this, anakinra (recombinant $\mathrm{IL}-1 \beta$ receptor antagonist) was used on a small group of patients, and there was a reduction in IFN- $\gamma$ induced protein 10 and CXCL10 (chemokine, CXC motif, ligand 10) levels. Also clinical improvement was observed (9).

Vitamin D: In addition to regulating calcium and phosphorus metabolism, it also has an immunomodulator effect. Vitamin D levels in PFAPA patients were found to be deficient and insufficient especially in winter. Vitamin D level is related with the number of attacks and CRP levels (29).

\section{Conclusion}

Timely and accurate recognition of the most common PFAPA syndrome among periodic fever syndromes can be achieved with good patient follow-up. Treatment options should be selected specifically for the patient with the help of a strong parent-doctor relationship.

\section{Ethics}

Peer-review: Internally peer-reviewed.

\section{Authorship Contributions}

Medical Practices: A.P.K., E.K.Ü., B.S., Concept: B.S., Design: A.P.K., E.K.Ü., B.S., Literature Search: A.P.K., E.K.Ü., B.S., Writing: A.P.K., E.K.Ü., B.S.

Conflict of Interest: No conflict of interest was declared by the authors.

Financial Disclosure: The authors declared that this study received no financial support. 


\section{References}

1. Marshall GS, Edwards KM, Butler J, Lawton AR. Syndrome of periodic fever, pharyngitis, and aphthous stomatitis. J Pediatr 1987;110:43-6.

2. Thomas KT, Feder HM Jr, Lawton AR, Edwards KM. Periodic fever syndrome in children. J Pediatr 1999;135:15-21.

3. Padeh S. Periodic fever syndromes. Pediatr Clin North Am 2005;52:577-609.

4. Adachi $M$, Watanabe $A$, Nishiyama $A$, et al. Familial cases of periodic fever with aphthous stomatitis, pharyngitis, and cervical adenitis syndrome. J Pediatr 2011;158:155-9.

5. Antón-Martín P, Ortiz Movilla R, Guillén Martín S, et al. PFAPA syndrome in siblings. Is there a genetic background? Eur J Pediatr 2011;170:1563-8.

6. Padeh S, Stoffman N, Berkun Y. Periodic fever accompanied by aphthous stomatitis, pharyngitis and cervical adenitis syndrome (PFAPA syndrome) in adults. Isr Med Assoc J 2008;10:358-60.

7. Vigo G, Zulian F. Periodic fevers with aphtous stomatitis, pharyngitis, and adenitis (PFAPA). Autoimm Rev 2012;12:525.

8. Stojanov S, Hoffmann F, Kéry A, et al. Cytokine profile in PFAPA syndrome suggests continuous inflammation and reduced anti-inflammatory response. Eur Cytokine Netw 2006;17:90-7.

9. Kolly L, Busso N, von Scheven-Gete A et al. Periodic fever, aphthous stomatitis, pharyngitis, cervical adenitis syndrome is linked to dysregulated monocyte $\mathrm{IL}-1 \beta$ production. $\mathrm{J}$ Allergy Clin Immunol 2013;131:1635-43.

10. Brown KL, Wekell P, Osla $V$, et al. Profile of blood cells and inflammatory mediators in periodic fever, aphthous stomatitis, pharyngitis and adenitis (PFAPA) syndrome. BMC Pediatr 2010;10:65.

11. Stojanov $S$, Lapidus $S$, Chitkara $P$, et al. Periodic fever, aphthous stomatitis, pharyngitis, and adenitis (PFAPA) is a disorder of innate immunity and Th1 activation responsive to IL-1 blockade. Proc Natl Acad Sci U S A 2011;108:7148-53.

12. Valenzuela $\mathrm{PM}$, Araya $\mathrm{A}$, Perez $\mathrm{Cl}$, et al. Profile of inflammatory mediators in tonsils of patients with periodic fever, aphthous stomatitis, pharyngitis and cervical adenitis (PFAPA) syndrome. Clin Rheum 2013;32:1743-9.

13. Akelma $A Z$, Cizmeci $M N$, Kanburoglu MK, et al. Is PFAPA syndrome really a sporadic disorder or is it genetic? Med Hypotheses 2013;81:279-81.

14. Berkun Y, Levy R, Hurwitz A, et al. The familial Mediterranean fever gene as a modifier of periodic fever, aphthous stomatitis, pharyngitis, and adenopathy syndrome. Semin Arthritis Rheum 2011;40:467-72.
15. Di Gioia SA, Bedoni N, Scheven-Gête A, et al. Analysis of the genetic basis of periodic fever with aphthous stomatitis, pharyngitis, and cervical adenitis (PFAPA) syndrome. Sci Rep 2015;5:10200.

16. Hofer M, Pillet $P$, Cochard MM, et al. International periodic fever, aphthous stomatitis, pharyngitis, cervical adenitis syndrome cohort: description of distinct phenotypes in 301 patients. Rheumatology (Oxford) 2014;53:1125-9.

17. Padeh S, Brezniak N, Zemer D, et al. Periodic fever, aphthous stomatitis, pharyngitis, and adenopathy syndrome: clinical characteristics and outcome. J Pediatr 1999;135:98-101.

18. Tasher D, Stein M, Dalal I, Somekh E. Colchicine prophylaxis for frequent periodic fever, aphthous stomatitis, pharyngitis, adenitis episodes. Acta Pediatr 2008;97:1090-2.

19. Gattorno M, Caorsi R, Meini A, et al. Differentiating PFAPA syndrome from monogenic periodic fevers. Pediatrics 2009;124:721-8.

20. Feder HM, Salazar JC. A clinical review of 105 patients with PFAPA (a periodic fever syndrome). Acta Paediatr 2010;99:178-84.

21. Wurster VM, Carlucci JG, Feder HM Jr, Edwards KM. Longterm follow-up of children with periodic fever, aphthous stomatitis, pharyngitis, and cervical adenitis syndrome. J Pediatr 2011;159:958-64.

22. Yoshihara T, Imamura T, Yokoi $K$, et al. Potential use of procalcitonin concentrations as a diagnostic marker of the PFAPA syndrome. Eur J Pediatr 2007;166:621-2.

23. Kovacs L, Hlavatá A, Baldovič $M$, et al. Elevated immunoglobulin D levels in children with PFAPA syndrome. Neuro Endocrinol Lett 2010;31:743-6.

24. Horwitz MS, Duan Z, Korkmaz B, Lee HH, Mealiffe ME, Salipante SJ. Neutrophil elastase in cyclic and severe neutropenia. Blood 2007;109:1817-24.

25. Padeh S. Periodic fever with aphthous stomatitis, pharyngitis and adenitis (PFAPA syndrome). www.uptodate.com. March 2015.

26. Tasher D, Somekh E, Dalal I. PFAPA syndrome: new clinical aspects disclosed. Arch Dis Child 2006;91:981-4.

27. Ter Haar N, Lachmann H, Özen S, et al. Treatment of autoinflammatory diseases: results from the Eurofever Registry and a literature review. Ann Rheum Dis 2013;72:678-85.

28. Burton MJ, Pollard AJ, Ramsden JD, Chong LY, Venekamp RP. Tonsillectomy for periodic fever, aphthous stomatitis, pharyngitis and cervical adenitis syndrome (PFAPA). Cochrane Database Syst Rev 2014:CD008669.

29. Stagi S, Bertini F, Rigante D, Falcini F. Vitamin D levels and effects of vitamin $D$ replacement in children with periodic fever, aphthous stomatitis, pharyngitis, and cervical adenitis (PFAPA) syndrome. Int J Pediatr Otorhinolaryngol 2014;78:964-8. 